\title{
The Use of Mentor Pollination to Facilitate Wide Hybridization in Blueberry
}

\author{
Timothy F. Wenslaff ${ }^{1}$ and Paul M. Lyrene \\ Horticultural Sciences Department, Institute for Food and Agricultural Science, \\ University of Florida, Gainesville, FL 32611
}

Additional index words. interspecific hybridization, heteroploid crosses, Vaccinium elliottii, Vaccinium corymbosum, seed development

\begin{abstract}
Two diploid yellowleaf Vaccinium elliottii Chapmn. clones were pollinated with pollen from the tetraploid southern highbush cultivar 'Misty' (largely $V$. corymbosum $L$ ). These interspecific crosses, which normally yield few hybrids because of a triploid block, were made with and without the use of $V$. elliottii mentor pollen mixed with $V$. corymbosum pollen. Mentoring had no effect on the number of hybrids produced when $V$. elliottii 'Silverhill' was the seed parent, but when $V$. elliottii 'Oleno' was the seed parent, no hybrids were produced unless mentor pollen was utilized. The difference was postulated to be a greater ability to produce one-seeded berries in 'Silverhill' than in 'Oleno'.
\end{abstract}

Blueberries (Vaccinium section Cyanococcus, family Ericaceae) are a diverse group of perennial, woody shrubs, mostly deciduous, which bear edible fruit in clusters. They are mainly distributed in eastern North America from Florida to Canada. There are diploid, tetraploid, and hexaploid species $(\mathrm{x}=$ 12 ), of which three have been developed and grown commercially on a large scale: lowbush ( $V$. angustifolium Ait., $2 \mathrm{n}=48)$, highbush $(V$. corymbosum, $2 \mathrm{n}=48$ ), and rabbiteye (V. ashei Reade, $2 \mathrm{n}=72$ ). For a comprehensive review, see Galletta (1975) and Luby et al. (1990).

Highbush blueberry domestication, based largely on $V$. corymbosum from New Jersey, began in the early 1900s. In about 1940, selection and breeding of rabbiteye blueberries began in Florida and Georgia. Improvement began with the primary gene pools, by intraspecific hybridization of selected wild seedlings. Later, breeders began to use other Vaccinium section Cyanococcus species in breeding (Lyrene and Ballington, 1988).

Several Florida native blueberry species have potential value for improving tetraploid highbush blueberries. Lyrene and Sherman (1980) evaluated the horticultural characteristics of diploids V. darrowi Camp and V. elliottii, and tetraploids $V$. fuscatum Ait. and $V$. myrsinites Lam. Diploid blueberry species do not cross readily with tetraploid highbush blueberries because of a strong triploid block that causes abortion of triploid zygotes (Ehlenfeldt and Ortiz, 1995; Muñoz and Lyrene, 1985).

An experiment was undertaken to test

Received for publication 27 Dec. 1998. Accepted for publication 7 Apr. 1999. Florida Agricultural Experiment Station Journal Series no. R-06657. The cost of publishing this paper was defrayed in part by the payment of page charges. Under postal regulations, this paper therefore must be hereby marked advertisement solely to indicate this fact.

${ }^{1}$ Current address: Hawaii Agriculture Research Center, 99-193 Aiea Heights Drive, Aiea, HI 96701. whether mentored pollination would improve the success rate of difficult hybrid crosses in blueberry, in this case, diploid V. elliottii $\mathrm{x}$ tetraploid Florida highbush 'Misty' (Lyrene et al., 1997). Mentor pollination is the use of a small amount of pollen that is highly compatible with the seed parent mixed with a large amount of pollen from the intended pollen parent to increase the possibility of success in wide hybridization. A simple way to separate the seedlings that result from the two types of pollen is important so that seedlings resulting from the mentor pollen can be discarded. Obtaining seedlings from a $2 \mathrm{x} \times 4 \mathrm{x}$ cross in blueberry depends on the rare occurrence of $2 \mathrm{n}$ gametes in the diploid parent, an event not likely to occur more than once in a given ovary, or on the rare survival of triploid embryos (Lyrene and Sherman, 1983). In the production of tetraploid hybrids from such a cross, the rare $2 \mathrm{n}=2 \mathrm{x}=24$ egg from the diploid parent unites with a normal $1 \mathrm{n}=2 \mathrm{x}=$ 24 pollen nucleus from the tetraploid parent to produce a $4 \mathrm{x}$ hybrid. If more than one viable seed is required to sustain normal berry development and retention, rare hybrids could be lost. We evaluated the use of mentor pollination to enhance fruit set and development, thereby avoiding loss of hybrid seeds. A recessive yellowleaf seedling marker gene in $V$. elliottii (Lyrene, 1988) provided a means of distinguishing the progeny of the mentor pollen from the interspecific hybrid progeny.

\section{Materials and Methods}

In December, four plants of the diploid yellowleaf $V$. elliottii clone 'Oleno', five plants of the diploid yellowleaf $V$. elliottii clone 'Silverhill', and one plant of a tetraploid Florida highbush blueberry cultivar with normal anthocyanin phenotype ('Misty', derived primarily from $V$. corymbosum), all propagated from softwood cuttings, were dug from the Univ. of Florida Horticultural Unit in Gainesville, pot- ted, and placed in a refrigerator at $\approx 5^{\circ} \mathrm{C}$. Both of the $V$. elliottii clones were known to be homozygous at the same locus for a recessive allele that makes the cotyledons and hypocotyls of newly germinated seedlings bright greenish-yellow instead of the normal greenish-red color. All the plants used in the experiment were 3 years old from rooted cuttings. After 1 month in the refrigerator, the plants were placed in a bee-proof greenhouse. The temperature in the greenhouse was maintained between 5 and $27^{\circ} \mathrm{C}$.

Flowers of $V$. elliottii were pollinated with pollen from 'Misty' or with 'Misty' pollen to which a small amount of $V$. elliottii pollen had been added (mentored). One half of each bush (divided vertically) received one treatment and the other half received the other. Fresh flowers from plants flowering in the greenhouse were used to load the thumbnail with pollen. To avoid self-incompatibility, pollen from $V$. elliottii 'Silverhill' was used as the mentor pollen in pollinating 'Oleno' plants, and pollen from $V$. elliottii 'Oleno' was used as the mentor pollen on 'Silverhill' plants. Flowers were emasculated shortly before anthesis and were pollinated immediately afterward.

For the mentored pollination treatment, a light dusting of the appropriate $V$. elliottii pollen was applied to the thumbnail first, followed by a heavy layer of 'Misty' pollen. The proportion of pollens in the blend was not quantified, but 'Misty' pollen was at least $10 \times$ more abundant than $V$. elliottii pollen. The thumbnail was pressed against the stigma of the flowers to transfer the pollen. Each flower received a single application of pollen. The number of flowers pollinated in each treatment was recorded.

The berries were harvested and counted as they ripened. The seeds from the mentored berries were extracted using a food blender; the seeds from the non-mentored berries were extracted by hand on paper towels and counted. All seeds of each treatment within each $V$. elliottii clone were combined, for a total of four seedlots. The following December, the seeds were surface-sown in pots of fumigated Canadian peat. The pots were placed in a greenhouse where the temperature was maintained between 5 and $27^{\circ} \mathrm{C}$ and were watered at least once a day. Redleaf (wildtype) seedlings were assumed to be hybrids, either triploid $R R y$ or tetraploid $R R y y$, and were counted and transplanted to flats of peat in a greenhouse for eventual planting in the field. The yellowleaf seedlings, assumed to be V. elliottii, were maintained in the germination pots for several weeks to allow red pigments to develop in any seedlings that were slow to express the redleaf phenotype. Seedlings that remained yellowleaf were then discarded after counting.

The chi-square test for independence was used to determine whether the ratio of the number of interspecific seedlings obtained divided by the number of flowers pollinated was the same or different for the mentored and non-mentored pollinations within each $V$. elliottii clone. 


\section{Results and Discussion}

Pollen mentoring did not overcome the triploid block to hybridization, which is strong in Vaccinium. The hybrids from our diploid $\mathrm{x}$ tetraploid pollinations were all tetraploid, as indicated by the high percent staining of their pollen and from their high berry set when they were intercrossed. One triploid hybrid, evident by very low pollen staining and almost complete lack of berry set when pollinated with tetraploid hybrids, was produced from $V$. corymbosum $\times$ V. elliotii crosses that were part of another study (Wenslaff, 1993).

The results of mentoring were genotypedependent (Table 1). 'Oleno' bushes showed a significant benefit from mentoring; nonmentored pollinations of 'Oleno' produced no hybrids. 'Silverhill' bushes produced interspecific hybrids with or without mentoring. Levels of hybrid formation for 'Silverhill', both mentored and non-mentored, were similar to the levels for mentored 'Oleno'.

The difference between these two clones in response to mentoring may have been due to variability in fruit-setting capability. Nonmentored 'Oleno' may lose its hybrid progeny because it frequently aborts single-seeded fruit; parthenocarpy has not been observed in this genotype. Non-mentored 'Silverhill' does not appear to lose its hybrid progeny due to lack of fruit set; many of the flowers pollinated without mentoring set parthenocarpic fruits, which were retained on the plants long after the seeded fruits had ripened. These results indicate that mentored pollination, utilizing a seedling marker gene to identify hybrids, can be of value for making heteroploid blueberry crosses if the seed parent tends to retain to maturity only those berries that contain more than one seed.

The success of the interspecific cross was not significantly reduced by the intraspecific mentor pollen, as evidenced by the similar levels of hybrid formation on 'Silverhill' with or without mentoring. This indicates that the mentor pollen method can be used without fear of reducing the formation of hybrids in

Table 1. Numbers of berries, seeds and hybrids from mentored and non-mentored crosses of diploid Vaccinium elliottii $x$ tetraploid $V$. corymbosum.

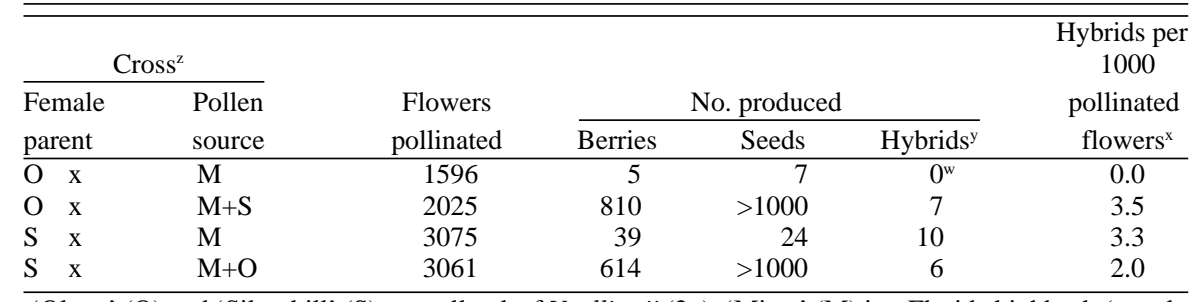

z'Oleno' (O) and 'Silverhill' (S) are yellowleaf V. elliottii (2x). 'Misty' (M) is a Florida highbush (mostly V. corymbosum) cultivar $(4 \mathrm{x})$.

yPlants with red leaves assumed to be interspecific hybrids.

${ }^{x}$ The ratio of number of hybrid seedlings obtained divided by number of flowers pollinated differed significantly for mentored and non-mentored pollinations on 'Oleno' seed parents according to the chi square test of independence, $\chi^{2}=3.92, P<0.05$. The ratios for mentored and nonmentored pollinations on Silverhill seed parents did not differ significantly different, $\chi^{2}=0.56, P>0.10$.

${ }^{\mathrm{w}}$ Two yellowleaf seedlings produced.

seed-parent genotypes that may not require mentoring. This result differs from the results Vander Kloet (1977) observed in crosses between diploid $V$. corymbosum and diploid $V$. darrowi Camp collected from Highlands County, Fla. In that combination, pollination with a mixture of intraspecific and interspecific pollen gave only nonhybrid progeny, i.e., interspecific pollen was not competitive with intraspecific pollen.

Mentoring may benefit blueberry breeders if the seed parent used normally fails to set fruits with only a few seeds. In the case of $2 x$ $x 4 x$ crosses, the level of success also depends on the level of $2 \mathrm{n}$ gamete formation in the diploid parent.

\section{Literature Cited}

Ehlenfeldt, M.K. and R. Ortiz. 1995. Evidence on the nature and origins of endosperm dosage requirements in Solanum and other angiosperm genera. Sexual Plant Reprod. 8:189-196.

Galletta, G.J. 1975. Blueberries and cranberries, p. 154-196. In: J.N. Moore and J. Janick (eds.). Advances in fruit breeding. Purdue Univ. Press, West Lafayette, Ind.

Luby, J.J., J.R. Ballington, A.D. Draper, K. Pliszka, and M.E. Austin. 1990. Blueberries and cranberries (Vaccinium), p. 393-456. In: J.N. Moore and J.R. Ballington (eds.). Genetic resources of temperate fruit and nut crops. Vol. I. Intl. Soc. Hort. Sci., Wageningen, The Netherlands.

Lyrene, P.M. 1988. An allele for anthocyanin-deficient foliage, buds and fruit in Vacciniumelliottii. J. Hered. 79:80-82.

Lyrene, P.M. and J.R. Ballington, Jr. 1986. Wide hybridization in Vaccinium. HortScience 21:5257.

Lyrene, P.M. and W.B. Sherman. 1980. Horticultural characteristics of native Vaccinium darrowi, $V$. elliottii, $V$. fuscatum, and $V$. myrsinites in Alachua County, Florida. J. Amer. Soc. Hort. Sci. 105:393-396.

Lyrene, P.M. and W.B. Sherman. 1983. Mitotic instability and $2 \mathrm{n}$ gamete production in Vaccinium corymbosum $\times$ V. elliottii hybrids. J. Amer. Soc. Hort. Sci. 108:339-342.

Lyrene, P.M., W.B. Sherman, and R.H. Sharpe. 1997. 'Misty' southern highbush blueberry. HortScience 32:1297-1298.

Muñoz, C.E. and P.M. Lyrene. 1985. Reproductive incompatibility barriers in crosses between Vaccinium corymbosum and V. elliottii. Can. J. Bot. 63:1987-1996.

Vander Kloet, S.P. 1977. Potential and actual gene exchange among three sympatric species of Vaccinium Section Cyanococcus in Highlands County, Florida. Can. J. Bot. 55:2668-2672.

Wenslaff, T.F. 1993. Hybridization in blueberries: pollination methods and characterization of hybrids. PhD Diss., Univ. of Florida, Gainesville. 